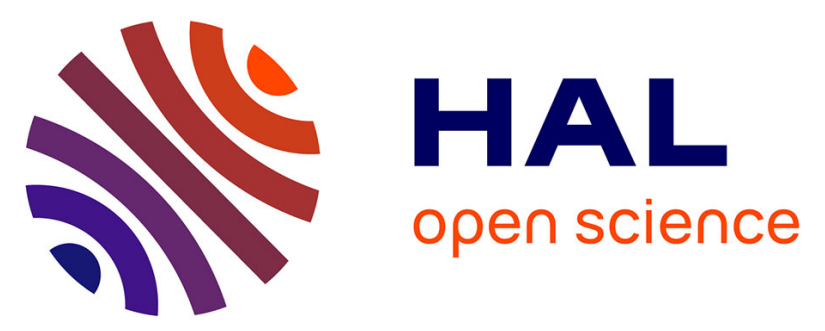

\title{
The brittle-to-viscous transition and its potential relationship to seismic deformation
}

Holger Stunitz, Sina Marti, Nicolas Mansard, Matej Pec, Hugues Raimbourg, Jacques Précigout, Renée Heilbronner

\section{- To cite this version:}

Holger Stunitz, Sina Marti, Nicolas Mansard, Matej Pec, Hugues Raimbourg, et al.. The brittle-toviscous transition and its potential relationship to seismic deformation. EGU General Assembly 2020, May 2020, Online, France. 10.5194/egusphere-egu2020-5522 . hal-03554438

\author{
HAL Id: hal-03554438 \\ https://hal.science/hal-03554438
}

Submitted on 3 Feb 2022

HAL is a multi-disciplinary open access archive for the deposit and dissemination of scientific research documents, whether they are published or not. The documents may come from teaching and research institutions in France or abroad, or from public or private research centers.
L'archive ouverte pluridisciplinaire HAL, est destinée au dépôt et à la diffusion de documents scientifiques de niveau recherche, publiés ou non, émanant des établissements d'enseignement et de recherche français ou étrangers, des laboratoires publics ou privés.

\section{(c)(1)}

Distributed under a Creative Commons Attribution| 4.0 International License 


\title{
EGU2020-5522
}

https://doi.org/10.5194/egusphere-egu2020-5522

EGU General Assembly 2020

(c) Author(s) 2022. This work is distributed under

the Creative Commons Attribution 4.0 License.

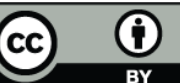

\section{The brittle-to-viscous transition and its potential relationship to seismic deformation}

\author{
Holger Stunitz ${ }^{1,3}$, Sina Marti ${ }^{2}$, Nicolas Mansard ${ }^{3}$, Matej Pec ${ }^{4}$, Hugues Raimbourg ${ }^{3}$, Jacques \\ Précigout ${ }^{3}$, and Renée Heilbronner ${ }^{2}$ \\ 1University of Tromsø, Dept. of Geology, Tromsø, Norway (holger.stunitz@uit.no) \\ ${ }^{2}$ Basel University, Dept. of Earth Sciences, Basel, Switzerland \\ ${ }^{3}$ Université d' Orléans, ISTO, Orléans, France \\ ${ }^{4}$ MIT, EAPS, Cambridge, Mass., USA
}

Strength profiles through the crust and upper mantle typically show the brittle to viscous transition as a change in deformation mechanism from frictional sliding to crystal plastic (dislocation creep) mechanisms. Even though such a change may conceivably take place, experimental evidence and natural observations indicate that a transition from semi-brittle to diffusion creep mechanisms rather than dislocation creep is more common.

In experiments we have carried out on granitoid and mafic rock material we can distinguish 3 main processes for the brittle to viscous transition: (1) Grain size comminution by cracking produces a sufficiently small grain size (sub-micron) to cause a switch to diffusion creep. (2) Amorphous material forms (aseismically) from mechanical wear at high stresses (high dislocation densities or high work rate) without melting. The amorphous material is observed to be weak and deforms viscously. (3) Nucleation of new minerals as a consequence of metastability of existing minerals at given $\mathrm{P}, \mathrm{T}$, fluid-conditions produces fine-grained and well-mixed aggregates causing a switch to diffusion creep as in (1).

The viscously deforming part of the crust or upper mantle is not the region where most earthquakes occur, because low stresses commonly are associated with viscous deformation. However, the transitions observed in experiments described above are transformational processes the material progressively evolves over a period of time in terms of microstructure, grain size, and/or composition, i.e., they are deformation-history-dependent transitions. In other words, during the transformation, only parts of the material deform by viscous processes while others have not evolved and are still brittle (and stronger). The bulk material strength of partially transformed rock depends on the connectivity of the weaker transformed material. The weaker material causes stress concentrations at the tips of transformed zones. The coalescence of transformed zones and/or a sufficiently large amount of transformed material is expected to cause catastrophic failure and thus seismic rupture. In such a way, transformation to viscously deforming weaker material may cause seismic behavior rather than according to the conventional view, where material properties change as a result of seismic deformation first, leading to creep. 
